\title{
Al-Ghazali's Image in Al-Jabri's works
}

\author{
Mohammed Lachkar \\ Moulay Ismail University, \\ Presidency, Marjane 2, BP:298, Meknes, Morocco, \\ med_lachkar@yahoo.fr
}

\begin{abstract}
Muhammad Abed Al-Jabri (1935-2010) is a famous philosophical and scientific figure in contemporary Arab thought. He is the author of the philosophy of "the Arab mind" and "the criticism of the Arab mind." He tried to establish his theory of looking at the ancient Arab heritage and modern Arab thought. He also tried to view them according to the critical vision criteria, which he laid the methodological foundations for in his essential philosophical writings, especially in the critique of the Arab mind trilogy. In this study, I seek to analyze and study various aspects of his analytical and critical approach towards Al-Ghazali and his theoretical creativity. As well as revealing the specificity of his position on the intellectual path of Al-Ghazali himself, based on the sequence of his books, Al-Jabri considered Al-Ghazali's personality as a large and complex problem, so that It is challenging to define entirely and accurately. However, this does not exclude him from the possibility of defining the criteria of science in general and philosophy in particular. In this research, I tried to reveal that the position of Al-Jabri himself represents in some sense the continuation of the problematic and complexity of Al-Ghazali himself. Al-Jabri raised more problems than the answer to them. And the controversy remains and is getting stronger. The research into the personality and works of Al-Ghazali seems to have been and will remain for a long time due to the problematic character of Al-Ghazali himself, the diversity and differences of his intellectual, creative writing, and his tortuous nature. Hence, this study constitutes a contribution in this field.

Keywords: Al-Ghazali, Al-Farabi, al-Jabri, Asharism. Arab Reason, Avicenna, Critique of Arab Reason, Esoterism, Ibn Roshd, Ismailism, Mu'tazilism, Sunnism, Shiism, Tahafut Al-Falasifa
\end{abstract}

\section{Article history:}

The article was submitted on 05.08.2020

The article was accepted on 01.01.2021

(C) Lachkar M., 2021

This work is licensed under a Creative Commons Attribution 4.0 International License https://creativecommons.org/licenses/by/4.0/ 
For citation: Lachkar M. Al-Ghazali's Image in Al-Jabri's works. RUDN Journal of Philosophy. 2021;25(2):233 - 249. DOI: 10.22363/2313-2302-2021-25-2-233-249

\section{Introduction}

In this paper, we intend to examine some characteristics of Hujjat al-Islam's imagery in the writings of the Moroccan thinker Muhammad Abed al-Jabri. We would like to point out, at the very start, that what has been stated by the author of Naqd Al- 'aql Al-'Arabì (Critique of Arab Reason) concerning Abu Hamid has been dispersed and distributed in a group of his studies. We, therefore, had to, at a descriptive level, gather this diaspora in an integrated way, which covers all the aspects of the intellectual project of Al-Ghazali. On an analytical level, we needed to appraise the extent of this imagery's harmony with what Abu Hamid transmitted in his vast work folds. As such, we will contrast the data provided by the narratives of our professor Muhammad Abed Al-Jabri regarding the Hujjat al-Islam and whatever supportive or destructive pieces of evidence of the image that was drawn by the writings of the author of Naqd Al- 'aql Al- 'Arabì (Critique of Arab Reason) to the author of Al Tahafut Al-Falasifa (The Incoherence of the Philosophers) mentioned in the texts of Al-Ghazali.

Without broaching through the Jabri methods, we note that it is about reading and not only research or study "because it goes beyond documentary research and analytical study... and it, explicitly and consciously, suggests an interpretation that gives the text a readable meaning, making significant to its intellectual, social, political environment, and also to readers" [1. P. 11]. Subsequently, and in the light of connecting the reader with the text, Al-Jabri invokes Al-Ghazali and Avicenna's claims, which he considered as play in their texts and which can only be revealed if we consciously engage in their intellectual problems and concerns [Ibid. P. 26].

Initially, Mohammed Abed al-Jabri sees that Al-Ghazali's thought components are the same components of the Arab-Islamic culture. The fifth Hijri century was entitled "the Ghazali moment" due to the culture's language at that time [2. P. 55]. However, the more he represented the Hujjat of Islam at a moment of maturity of these components and their arrival at a moment of certain perfection, the more his intellectual experience expressed the underlying conflicts between them and revealed the paradoxes inherent in their delirious harmony. The fifth Hijri century, from al-Jabri's point of view, is a defining moment that divides the history of ArabIslamic culture into two parts: the first starting from the era of codification at the time of Hujjat Al-Islam, and the second starting from that time till today [3. P. 161]. In this case, we agree with Muhammad Abed al-Jabri regarding Al-Ghazali's ideas and the difficulty of writing about them. We, then, may disagree with him on a set of conclusions and inferences that he drew from his readings of Abu Hamid's works, particularly when he places Al-Ghazali in an interpreter position. 


\section{Components of Al-Ghazali's thinking}

While we examine Al-Jabri's perception of Abu Hamid's thought components, we caution that Al-Jabri was not against the tendency to specialize in his research practice. He, instead, stressed the need to consider within the specialization department the interdependence between the specializations of the culture of the past: "the jurist was a grammarian and a grammarian jurist, and we may find them both among speakers or rhetoricians. Just as our cultural history witnessed, scholars in mathematics, astronomy, there were also philosophers such as Al-Ghazali and Ibn Hazm, and jurists such as Avicenna" [4. P. 45]. According to Al-Jabri, our past heritage's multiplicity and diversity assert that integration and unity, which our current cultural history neglects [Ibid. P. 45]. We also note that what most distinguishes Al-Jabri's approach to heritage is his work according to subdivisions and taxonomies academic divisions' mentality. His tripartite division of the cognitive systems prevailing in Arab-Islamic culture (statement, proof, gratitude) remains a solid witness to what we mention. Integration and unity, on the one hand, and division and exclusivity, on the other, are the two safe methodological approaches to treating and examining our heritage, according to what the critic of the Naqd Al- 'aql Al-'Arabì (Critique of Arab Reason) practiced.

Al-Jabri reviews the manifestations of what he calls the "foundations crisis" in Arab thought, which, in its perception, is due to the collision and overlap of competing cognitive systems within. Firstly, the statement with the proof on the one hand, secondly the proof with gratitude, and thirdly the statement with the gratitude [Ibid. P. 277]. The three cognitive systems in Al Jabri's point of view are clashing intellectual structures and not conflicting opposites. Therefore, it was natural for the collision and interference to surface from a bilateral clash to a general one among all of these structures. Those above was embodied in the spiritual experience and intellectual production of the Hujjat Al-Islam, whose writings reviewed the narratives and theses of various currents and intellectual doctrines that the Arab thought witnessed [Ibid. P. 277-278].

Al-Ghazali, according to al-Jabri, adopted in his books, which he classified after the Tahafut Al-Falasifa (the Incoherence of the Philosophers) and Al Fada'ih, the same theses that the philosophers disbelieved "not in a deductive manner, but in an esoteric ritualistic manner by dressing it in a Quranic form. Al-Ghazali remained hostile to the philosophers in reference to the issue of causation. Hujjat Al-Islam has worked hard to reconcile between its graphic poetry and its mystical gratitude. What he evoked in The Jewels of the Qur'an is proof of that. He presented a hermetic reading of the Qur'an and its linguistic and religious sciences employing chemical and Hermetic religious concepts" [Ibid. P. 286].

According to the tripartite division of epistemological systems, al- Ghazali's structure appears to be a heterogeneous mixture. Abu Hamid singled out the public with the statement and the private with recognition, but he did not separate the public from the private. "Therefore, he did not separate between statement and recognition, rather made statement a path towards recognition, just as the public 
was a composite of the private. On the one hand, he took Hujjat Al-Islam from the content statement and the form from proof and dedicated it to the public. On the other hand, he took the form from the statement and the content from recognition and dedicated it to the private. According to Al-Jabri, Al-Ghazali canceled the content of the proof, which is causation, and thus the mathematical and natural mental sciences" [Ibid. P. 287].

The resigned mind in Al-Ghazali has triumphed over all his competencies in jurisprudence and speech. In other words, the transcendental Hermesian won over the earthly, religious militant jurist, scaring the Arab mind deeply [Ibid. P. 287].

Authors distinguish between three stages in the Abbasid era, within which Al-Ghazali represents the middle stage. Al-Jabri believes that Arab culture has remained, to this day, one cultural age, including the after and before codification era. As such, Al-Ghazali did represent neither the beginning nor the end of the Arab mind era. This era weaved between three knowledge systems, portraying a clash and an overlap, to which the Arab thought failed to achieve a final rupture or rearrange the relations in a way that allows the launch of a new beginning that puts a final separation between the before and after [Ibid. P. 288].

The components of Al-Ghazali's thought, in Al-Jabri's conception, are the components of the entire Arab-Islamic culture. Al-Ghazali reflected the culture of his time and a meeting point for the various intellectual and ideological currents that Arab and Islamic thought knew during the era. Currents that were finally perfected to Hujjat Al-Islam, expressing the extent of its diversity and the expansion of its horizons, its conflicts, and contradictions, and most importantly, according to Al-Jabri, the moment of its crisis. Al-Ghazali's thought components witnessed two historical sessions; a first session that ends with Al-Ghazali and a second one that begins with him. If it was necessary to define a point dividing Arab-Islamic thought from the era of codification to this day, to the before and after, this point would be, in Al Jabri's view, the Al-Ghazali moment that best explains what was before and after [3. P. 161-162].

Al-Jabri acknowledges the difficulty of reading Al-Ghazali, be it at the level of understanding and interpretation or deconstruction and reconstruction. What increases this difficulty is the fact that if we can read in it a starting point or an ending point, we, consequently, cannot separate the two points, nor establish a kind of rupture between them, since the thought of Al Ghazali is dominated by a straight, fractured connection [Ibid. P. 162].

Verbally, we cannot say that the author of Al-Iqtisad resumed what his professor Al-Juwayni started, defending the Ash'ari against the Mu'tazila and philosophers. Al Jabri warns that Al-Juwayni's response to the philosophers was a verbal, external, and dysfunctional response, in contrast to Abu Hamid's response, which was a philosophical, internal, and sturdy response [Ibid. P. 162].

Fundamentally, Hujjat Al-Islam did not resume what Al-Shafii' ended up staying in his message when he legalized the opinion and the origin of the fundamentals. The distance between Al-Risala (the message) and Al-Mustasfa (The 
Chosen)is long and complex. The author of Naqd Al-'aql Al-'Arabī, points out, what he calls a systematic break between the Shafii linking knowledge of the Arab language with fundamentals of Sharia, and Al-Ghazali's linking knowledge of Aristotelian logic with the validity of all sciences, jurisprudence and its origins included [Ibid. P. 162].

Mystically, it cannot be said that the author of Ihya ulum addine (The Revival of the Sciences of Religion) resumed what Al-Qushayri and Al-Muhasibi started. These latter gave Sunni legitimacy to Sufism in their works. The Sufi model of Hujjat Al-Islam, in Jabri's conception, has a particular specificity compared to its predecessors, which is confirmed by the author's numerous hints and references to what he calls the science of disclosure [Ibid. P. 163].

Logically, Al-Ghazali did not resume what Al-Farabi started in adapting logic in Arab-Islamic culture, nor what Ibn Hazm started in the process of approximation and Arabization. If this latter scholar wishes for logic to be a method for acquiring knowledge in an evidentiary way through certain premises, then the author of Mi'yar Al-ilm (The Standard of Science) the standard, with open pretensions, wants it to be a weapon that either defends or nullifies. On the other hand, if Hujjat Al-Islam was selective in its engagement with the forms of recognition by accepting the Sufi and rejecting the Ismaili Emami, the Sheikh of Dhahiriya, was, consequently, decisive in his response to all forms of recognition [Ibid. P. $163-164]$.

These examples, according to Al-Jabri, confirm that the thought of Abu Hamid is not, merely, a continuation of what preceded it, since, despite its organic connection with previous personalities and doctrines, is a thought that contains components other than those that can be referred to before its existence. These new components indicate that $\mathrm{Al}$ Ghazali was an endpoint for what came before him and a starting point for what came after him. Accordingly, from the fifth Hijri century to the present day, Al- Ghazali has become one of the main components of Arab-Islamic thought and one of its reference powers. It is a moment of many beginnings that, upon its completion, turned into a wholly beginning whose end is not yet known to this day [Ibid. P. 165].

In his exploration of the components of the thought of Hujjat al-Islam, Al-Jabri refers to a unique picture presented by the orientalist Wensinck to Al-Ghazali, who considered Abu Hamid a Muslim as a speaker, a modern Platonic as a thinker and man of knowledge, and a Christian as an ethical and a mystic individual. The author of Naqd Al-'aql Al-'Arabi (Critique of Arab Reason) will accept the first two components only to reject the third component because accessing religious books from the Bible, the Torah, and others were not something that was reserved for AlGhazali alone. Rather, his numerous references to Christian evidence are insufficient to raise the influence that Christianity may have influenced his thought, similarly to Islam and Neoplatonism [Ibid. P. 167-168].

The shortest way to know the components of Al Ghazali's thought is to view it not as the thought of a particular man but as an intellectual phenomenon in 
Arab-Islamic culture that has been present for the past nine centuries. On this basis, Al-Jabri poses a bold question: What would the Arab-Islamic culture have lost had Al-Ghazali not written anything? The author of Naqd Al-'aql Al-'Arabi (Critique of Arab Reason) responds that culture would have lost three books: The Revival of the Sciences of Religion, The Incoherence of the Philosophers and The Standard of Science. The rest of Abu Hamid's writings are either insignificant, or their content is present in one or another way in this trilogy [Ibid. P. 169].

The reason Ihya Ulum Addine (The Revival of the Sciences of Religion) was distinct from other Sufi texts in Al Jabri's conception was not its substance alone. It is the same material that we find in similar texts such as Qüt al-qulüb (Sustenance of hearts) and Alri'aayah li hoqoq Allah (Care for the rights of God) Rather, what distinguished it was the way that material was presented, employed and how it was invested. Abu Hamed contrasted between the science of engagement and the science of reveal to ease the way for Sufism [Ibid. P. 169].

Al-Jabri considers Tahafut Al-Falasifa (the Incoherence of the Philosophers) as a single and unique text in Arab-Islamic culture, "it was not composed before or after al Ghazali, and its influence in preventing Arab Islamic thought from philosophy is matched only by the influence of the book" [Ibid. P. 170, 171]. Accordingly, Naqd Al-'aql Al-'Arabī (Critique of Arab Reason) confiscates an orientalist position that De Boer established when he claimed in his book History of Philosophy in Islam that Al-Ghazali was the cause of the elimination of philosophy in the Arab-Islamic culture [5. P. 316-355].

The Hujjat Al-Islam, in his writing Tahafut, Al-Falasifa (the Incoherence of the Philosophers) according to Al-Jabri, treated philosophy differently since the philosophy of Abu Al-Walid had its list not in the house of Islam, but Christian Europe. According to al-Jabri, the historical reality indicates that rational philosophy, after Abu Hamid's criticism, did not exist in Islam's land. This historical reality can only be explained by alerting to the role that the book Al-Tahafut played as being at the top of the list of factors and causes that ended the existence of philosophy in the Islamic city [3. P. 171].

As for the third most crucial text of Hujjat al-Islam, with regard to Al-Jabri, it is the book The Standard of Knowledge. Although this work does not rise to the rank of the first ones in content and influence, it remains, undisputedly, the most critical logical book of the Imam. Based on a brief presentation and analysis, the author of Naqd Al- 'aql Al- 'Arabì (Critique of Arab Reason) concludes that the Standard, clearly, expresses the effort made by Al Ghazali in preaching Aristotelian logic and inviting its adoption as a scale for thought and a standard for knowledge, in order to establish what the author of Al-Muqaddima (The introduction) calls the method of the later [Ibid. P. 171].

Al-Jabri asserts that Al-Ghazali's thought is determined based on these three books that depict a state of thought that contradicts itself. The first Revival enabled Abu Hamid to re-establish Sufism and triumph in its name, and through Al Tahafut, he attacked philosophy and nullified its divinities [Ibid. P. 171-172]. 
Al-Jabri believes that it is not right to call Hujjat al-Islam to mysticism and at the same time to attack the divinities of the philosophers, especially since the knowledge of this latter knowledge is, directly, derived from Avicenna's theology and the Ismaili philosophers. On the other hand, the combination of attacking philosophy and defending Aristotelian logic cannot be accepted, for Aristotle's logic is organically bound with his metaphysics. Abu Hamid's taking of instrumental conception of logic indicates that the attack on philosophy is specific and not general. The biggest contradiction in Islam's argument remains, its call for mysticism on the one hand and its propaganda of logic on the other hand. The Imam submerged between the two methods of disclosure and reasoning that do not meet in the opinion of al-Jabri [Ibid. P. 171]. However, the contradiction in Al-Ghazali's thought is not emotional and reflexive, but rather that of an active militant. Pre-Al-Ghazali era is helpful in determining the building material, but the era of Abu Hamid dictated how that material was invested, and defined the goals that he aimed. Al-Ghazali was a philosopher of the same state in which he lived in a total ideological sense before and after his psychological crisis and temporary isolation [Ibid. P. 173].

The critique of the Hujjat al-Islam of the esoteric political and religious views would have required the nullification of their philosophy, which was, in Jabri's conception, nothing but a modernized Platonicism in the form of the Orientalist Hermetic. Al-Ghazali's attack on philosophy was part of his war against esotericism, since Abu Hamid classified Tahafut (The Incoherence of The Philosophers) for Fada'ih Al-Batiniya (Esoteric scandals). On this basis, the call to make logic a sole method of knowledge was not a call for the sake of logic itself. Instead, on the one hand, it represented the optimal response against the theory of Ismaili mystical education, and on the other hand, a salvation of the science of Ash'ari theology from its internal crisis that almost plagued it because of the contradictions of rational premises. As for Al-Ghazali's bias towards Sufism, it remains an understandable and justified matter for Al-Jabri, because Sufism at the time represented the ideological and organizational basis of the Seljuk state. Al-Ghazali realized that it was impossible to substitute logic for the spiritual aspect of Shi'ite ritualism, so he stripped esoteric mysticism from its political cover that characterized it the Emami and Ismaili Shiites, and employed it as Sunnis. The call to mysticism, fight against philosophy, and the victory of logic are contradictory choices at the level of abstract thought, but at that time, they formed, for Hujjat alIslam, integrated weapons directed towards one opponent in terms of politics and political ideology [Ibid. P. 174].

\section{Al-Ghazali and Philosophy}

As we are in the process of observing the basics of Al-Ghazali's relationship with philosophy in Al-Jabri's conception, the author of Naqd Al-Aql Al-Arabi (Critique of Arab Reason) provides us with a very accurate comparison with two ends which are the argument of Islam and Al-Farabi. While al-Farabi confined 
himself to the divine Plato and the philosophy of Alexandria and tried to combine the two wise conceptions, Al-Ghazali disassembled Greek thought into bits and pieces and issued an opinion concerning every piece. He diminished mathematics, logics and natural sciences, rejected the divinities altogether, and authorized looking into the politics and ethics of philosophers [1. P. 116-117]. "Al-Ghazali chose from the Greek thought, the Torah, the Bible, the Persian and Indian heritage and the forged and questionable hadiths, whatever addressed his concerns and interests, and suited building his vision which was indicated to him through the historical era that he witnessed" [Ibid. P. 117]. While Al-Ghazali took an interest in fractions, and insisted on differentiation and distinction, Al-Farabi cared about the whole, intending to unify and reconcile. However, in Al-Jabri's conception, the issue is not due to Al-Ghazali's inability to perceive the totalities and to grasp the compounds, nor to Al-Farabi's inability to perceive the specificities and capture the particles [Ibid. P. 117]. The difference between these two eminent reflects two different development stages in the East's Arabic and Islamic conceptions. Al-Farabi oriented towards Aristotle to construct his virtuous city under the influence of different facts from that of Abu Hamid, which led him to Plotinus and Jesus to revive the sciences of religion in his time. "Indeed, Al-Farabi and Al-Ghazali's era concerning the development of the Arab-Islamic civilization in the East are respectively as that of Aristotle and Plotinus to the Greek civilization" [Ibid. P. 117-118].

Al-Jabri speaks of methodical factors that guided al-Ghazali in his reactions and choices, as it occurred during the Ash'ari coup against the Mu'tazila. His position on the different types of seekers of truth such as the discerners, Batiniyya (Esoterics), philosophers, and Sufis was subject to the state's ideology founded on the combination of Shafi'i jurisprudence, Ash'ari belief, and mysticism [4. P. 279].

Al-Ghazali's position on the different categories of seekers was dictated by the state, as he wrote a response to Al-Batiniyah (Esoterics) at the request of the Caliph Al-Mustadhiri. In this context, Al-Jabri alerts us that the response required both the knowledge of Ismaili philosophy and a return to philosophy in general; consequently responding to philosophers giving the organic link between Ismaili philosophy and Greek philosophy as decided by Avicenna [Ibid. P. 279].

Al-Jabri notices the fact that the Orientalists differed in translating the phrase "the incoherence of the philosophers" as some translated it "collapse," "fall," and "destruction," others translated it as "lack of cohesion" or "the death of cohesion." However, Henry Corbin objected to these translations and suggested the meaning of "self-destructing" because the Incoherence of Philosophers means that they destroy themselves by themselves, and thus their philosophical discourse contradicts each other. Accordingly, Al-Jabri believes that the meaning of self-destruction suits Ibn Sina perfectly [Ibid. P. 263].

According to the writer of Naqd Al-Aql Al-Arabi (Critique of Arab Reason), Avicenna's philosophy is the philosophy of self-destruction, not only because its owner did not abide by the rules of Aristotelian logic in presenting its issues as 
Al-Ghazali accuses him, but also a philosophy of a reason whose ultimate ambition is to be free. As a pioneer of the universal mind's inauguration in Arab culture, Al-Jabri believes that nothing justifies Avicenna's process of self-destruction in which he was led by his oriental philosophy devoted to the absurd and surrendered to the hermeneutics and its sorceress view of the world [Ibid. P. 263].

In his book Tahafut, Abu Hamid attacks both Ibn Sina and al-Farabi concerning the issues in which they disagree with the Ash'ari, while he kept quiet about the Shiites despite his claim that he has made all the sects against them. Accordingly, Al-Jabri interpreted this silence because the argument of Islam places the Shiites and philosophers in one place; ergo, The Incoherence of the Philosophers was for Fada'ihal-Batiniyah (Esoteric scandals). Philosophers at the time were not a source of danger to the fundamentals of religion, as Al-Ghazali claims, rather Al-Batiniyah (Esoterics) were so. In his response to philosophers, Abu Hamid targeted Avicenna precisely because his philosophy strongly related to Ismaili philosophy. Al-Ghazali did not stop at explaining the dilemma and contradiction of philosophers due to their failure to adhere to the conditions of proof but went further issuing a jurisprudential fatwa in their right, so he called them unbelievers in three issues and accused them of heresy in seventeen others. According to al-Jabri, these two manifestations are a single political reaction against the Ismaili movement [Ibid. P. 282-283].

Consequently, Al-Ghazali's spiritual crisis was caused by Abu Hamid's compulsion to nullify the opinions of Al-Batiniyah (Esoterics) and the philosophers that resort to or believe in some of its aspects. Judge Abu Bakr Ibn al-Arabi and Ibn Taymiyyah did not miss this issue, and they both warned that the argument of Islam in his thought and Sufism was affected by the views of Al-Batiniyah (Esoterics)and philosophers. Abu Hamid's crisis is related to choosing between staying connected to the state and liberating himself from it [Ibid. P. 283].

We are surprised by this artificial alignment that al-Jabri drew between Al-Batiniyah (Esoterics) as a discourse group with a political horizon and Greek philosophy in its image of Avicenna. On the other hand, Al-Jabridoes not state that Al-Ghazali's view on the different types of seekers was dictated by the state except for a contemporary saying of Averroes when he responded with, as speculation, Tahafut-Tahafut (the incoherence of the incoherence) Al-Ghazali to the wills of the people of that time.

It is noted that the discourse of the argument of Islam about philosophy takes place through sections rather than the method of total rejection. Some ideas can be an atonement, innovative, and others cannot be ultimately denied. In the Introduction of Al-Munqid (Deliverance from Error), we read that philosophers, despite the multitude of their sects and different doctrines, are divided into three parts: the evolutionists, the naturalists, and the divine. In this regard, Ahmed Alami Hamdan indicates that Al-Ghazali did not direct his response to all philosophers, but a particular philosopher, Aristotle, according to what was reported by Al-Farabi and Avicenne. Abu Hamed accepted philosophy altogether, as he chooses from all 
philosophy studies one topic worthy of a response, which is the divinities [6. P. 51-52]. While adopting what was stated by Professor Ahmed Alami Hamdan, we disagree with Muhammad Abed Al-Jabri and Farid Jabre. In one of the publications about the book On the Harmony of Religions and Philosophy, Al-Jabri described Al-Ghazali's Tahafut as a cruel interrogation and an arbitrary investigation of free thought, similar to the Inquisition that accused all those who disagreed with Catholicism, directly or indirectly, with Hersey and punished them [7. P. 21-40]. Farid Jabre also considered the book of Tahafut as an argument or indictment against philosophy rather than honest and objective criticism [8. P. 324].

On the other hand, regarding the presumed primacy of Al-Jabri's Fada'ih al-Batiniyah (Esoteric Scandals) over Tahafut (The Incoherence of The Philosophers), we present a dissenting opinion of the Egyptian researcher Abd al-Rahman Badawi in his study marked by the writings of Al-Ghazali, in which he combined between the chronological arrangement and the correctness of their lineage to the Imam. In the first section of the book devoted to the works that indeed belong to Abu Hamed, they are ranked as follow: Aims of Philosophers number16, The Incoherence of the Philosophers number 17 [9. P. 63], Mizan al- 'amal number 21 [Ibid. P. 79], Fada'ih al-batiniyah (Esoteric scandals) number [Ibid. P. 82], Moderation in Belief number 25 [Ibid. P. 87], and Ihy'a (The Revival of the Religious Sciences) number 28 [Ibid. P. 98]. This classification indicates the temporal precedence of criticism of philosophy over the criticism of Al-Batiniyya in the Hojjat al-Islam project.

According to Al-Jabri's view, one may wonder if Al-Fada'ih followed by Tahafut fight the Neo-Platonism? A group of scholars, who studied Al-Ghazali's works, generally agree on the influence of Neo-Platonism on the Hujjat al-Islam, but this agreement turns into a disagreement as soon as we initiate the determination of the nature and grounds of those influences. The shape, extent, and time of imprinting Abu Hamid's thought with neo-platonic features differ between Pierre Duhem, Wensinck, and Abdel Rahman Badawi. For Duhem, Al-Ghazali began as a Neo-Platonic to turn to a critic of this philosophy in which he believed [10. P. 136]. As for Wensinck, he only believed that Al-Ghazali was and remained faithful to his Neo-Platonism [11. P. 6, 10, 12, 13, 27, 199]. Whereas Abd al-Rahman Badawi considered that the Hujjat al-Islam began in Aristotelianism and ended with a Neo-Platonic [12. P. 237].

According to al-Jabri, Abu Hamed adopted the Hermetic religious philosophy with its fundamental theses in his Sufism. However, he did not know the Hermetic sources, as he drew the theses of the "the resigned mind" from Avicenna and alBatinah and their philosophers, particularly from Sufis Al-Bastami, Al-Hallaj, and Al-Junaid. Al-Jabri provides examples that depict the extent of Al-Ghazali's involvement in Hermeticism as he establishes a crisis in the Arab mind, as he refers to different ranks of existence in the books of Ma'arij al-Quds (purity's ascensions) and Ma'arif Aqlia (Mental Knowledge), which are close in form and content to the Hermetic theory [4. P. 283-284]. Al-Jabri took certain parts from the Hujjat 
al-Islam and arranged them according to his perspective to conclude that $\mathrm{Abu}$ Hamid said that the world is old and denies Allah's knowledge of the particles. He denies resurrection, which is why he called philosophers disbelievers in his Tahafut (The Incoherence of the Philosophers), on the premise that Hermetic Sufism is based on the denial of bodies in the world Before the Hereafter. Additionally, amalgamation and unity of existence is based on what our professor calls the "melting" of souls, ignoring the peculiarity of the Sufi Al-Ghazali model compared to other people of the Jubbah [Ibid. P. 286].

In his book Deliverance from Error, Al-Ghazali talked about what he went through during his illness about fourteen years ago, and accordingly, the book is not a diary but memories. Perhaps "Al-Ghazali was reconstructing his experience latter, and from a later standpoint, and not restoring it as it already was" as Al-Jabri portrays [Ibid. P. 281]. However, Deliverance from Error remains one of the valueadded texts as a whole. The book narrates in a very detailed image the author's journey between what he benefited from Islamic scholastic theology, the methods scholars, the methods of philosophizing, and the methods of Sufism. Abu Hamid's life appears to be "coherent in parts, the first of which is beautifully related to the last" [5. P. 327]. Herein lies the actual value of this compilation/testimony, in contrast to al-Jabri's attempt to downplay the importance of the hujjat al-Islam about himself in the Deliverance from Error, claiming that it is a conception primarily defined by the new trends of the Imam, represented in his transition to Sufism. Perhaps our imam only wrote "what saved him from misguidance" to knowledge, not the way of his transformations. However, it is hard to fully know him, our consolation remains his book, Deliverance from Error. This standpoint is recommended by a few scholars such as Maythem al-Janabi [13. P. 9] and Nakamura who says about Deliverance From Error "it is True and widely trusted, and that his two crises — that is, the two crises of Abu Hamid - express historical facts that are not subject to suspicion unless someone can testify otherwise" [14. P. 49].

\section{Al-Ghazali's logic}

As it is known, the author of Muqaddimah (Introduction) divided the verbal heritage into two categories; the first type is what was written by the pioneers, such as the works of al-Ash'ari, al-Baqilani and others, and the second category is what was written by the laters, one of which is al-Ghazali, followed by al-Fakhr al-Razi and Adud al-Din al-Iji and others. The first were distinguished by their aversion to the image of Greek evidence and syllogisms, at a time when the second embraced Greek logic realizing the difference between the tool of reasoning (logic) and the subject matter which is the speech of philosophers in physiology and theology, which was contrary to the recited tradition [15. P. 141-150]. By adopting this division, Ibn Khaldun enacted a well-established tradition for historians of Islamic thought first and researchers in its fields second. As Muhammad Abid al-Jabri did not hesitate to criticize this proposition and described Hujjat al-Islam as the first 
authors about the second method in terms of form and commitment to the method of pioneersin terms of content [16. P. 49].

The Ash'ari, starting with Al-Ghazali, abandoned the verbal institutions in their old form, and adopted Aristotelian logic, which is the way of the latter in Ibn Khaldun's expression [4. P. 118]. The author of Muqaddimah described the method of the pioneers by saying, "The invalidity of the evidence permits the invalidity of the signified", and others expressed it by saying "What has no evidence must be denied" [1. P. 216]. The latecomers noticed the weakness and excesses of the pioneers' arguments and resorted, from the fifth century AH, to Aristotelian logic. Although Al-Ghazali criticized this type of reasoning in the beginning, and consolidated this method of latecomers, he used it in his response to philosophers justifying resort to it as an attempt to confuse them and nullify their words, rather than proving a specific case [Ibid. P. 217].

Hujjat al-Islam uses these philosophers' weapons against them, that is, by debating them using their logical discourse, trying to prove that the requirements of the validity of the measuring material and its image in the proof section, and their description in the books of Al-Madkhal and Categories, could not be fulfilled in their sciences of divinity [Ibid. P. 217]. Al-Jabri raises a question: How could alGhazali question the propositions of the philosophers? Al-Ghazali's response was directed to Avicenna's interpretations the philosophers' discourse rather than the philosophers themselves. It was easy for Al-Ghazali, the Ash'ari speaker, to oppose the Sheikh with the same weapon because the latter did not adhere, as Ibn Rushd noted, to the evidentiary method in his presentation of philosophical issues, and adopted the inference of the witness over the absent as a method [Ibid. P. 217].

The intense verbal controversy with the Mu'tazila, the ideological differences with Al-Batiniyya (Esotericism) which found a place in the political practice, added to the conflict between the Hanbalis and the great Ash'ari leaders, starting with the Baqilani, may distract us from paying attention to the interactive dimension which is an essential and vital dimension in the Ash'ari discourse. This discourse represents a common ground between the Arab-Islamic civilization on the one hand and the Greek, Persian, and Indian cultures on the other. Accordingly, Aristotelian logic's influence on the Arab-Islamic culture will be nothing but a manifestation of this interactive dimension [17. P. 12-13].

Al-Jabri believes that Al-Ghazali's position on logic was built in a specific context among its features the difficulties encountered by Ash'ari speech after Al-Baqillani, and Al-Juwaini inauguration to work in the way of the latecomers that abandoned the inference of the witness rather than the absent and adopted the Aristotelian analogy. In al-Jabri's conception of logic, al-Ghazali needed to determine the doctrines of the Ash'ari against the Mu'tazila, who remained loyal to their preferred method of an analogy of the absent rather than the witness. Al-Ghazali also needed logic to respond to the educationalist who nullified the opinion and the analogy and believed in learning from the infallible teacher. Finally, Al-Ghazali needed logic to explain The Incoherence of the Philosophers. According to this arrangement and al-Jabri's conception, Abu Hamid's debates begin with 
Gentiles, the Mu'tazila, then al-Batiniya second, and then the philosophers third [4. P. 280].

Al-Ghazali seeks controversy from logic rather than proof. He wants to use it to defend the Ash'ari school of theology, the Shafi'i school of jurisprudence, and respond to other schools of thought. According to Al-Ghazali, logic is identical to the argument in Aristotle's terminology, inferring positively or negatively in one particular issue while avoiding contradiction and defending the positive or negative result [Ibid. P. 281].

Although we prefer to admit the Instrumentalism of logic according to Al-Ghazali, we need to read these debates in full respect to the chronological classification. Chronological studies indicate that the text Fada'ih Al-Batiniyah (Esoteric Scandals) follows Maqasid Al-falasifa (The Purposes of the Philosophers) and Tahafut Al-falasifa (The Incoherence of the Philosophers). Abd al-Rahman Badawi mentions in his book The Writings of Al-Ghazali that the book Aims of Philosophers occupies the 16th rank immediately The Incoherence of the Philosophers [9. P. 63]. The book Fada'ih Al-Batiniyahis ranked 22 [Ibid. P. 82] after the book Mizan al- 'amal (Work balance) listed in Rank 21 [Ibid. P. 79]. While five works of Hujjat al-Islam about logic are mentioned according to their historical sequence, according to the following order: Maqasid Al-falasifa (The Purposes of the Philosophers), Mi'yarAl'ilm (Science Standard), Mihaqannadhar (Touchstone of Consideration) Al-Qistas Al-mustaqim (Straight Scales), and the al-Mustasfa (The Chosen) [18. P. 58].

Returning to the compilations that Al-Ghazali appropriated or dealt with logic issues may reveal that he only worked to transmit the Greek logical heritage with the Roman additions that followed it, especially the book of Isagoge by Porphyr. The latter influenced the views of Muslim discourse concerning limit and significance [19. P. 88]. Al-Ghazali's works about logic evolved from a transfer of logic to its modification to a tool used in Islamic jurisprudence and Ijtihad (Diligence). Abu Hamid began to transmit the logic of Aristotle through Avicenna to a gradual path between logic and Islamic sciences. He made logic an Islamic science in terms of methodology and terminology and printed it with the features of the Arab-Islamic mentality [18. P. 59].

In his first book about logic, the Maqasid Al-falasifa (The Purposes of the Philosophers), Abu Hamid was subject to the influence of Avicenna ${ }^{1}$, and found nothing in al-Maqasid but an Arabic translation that respected what was mentioned in a Persian text that Avicenna had titled Dànesh Nàmeh [20. P. 231]. Hujjat al-Islam in al-Maqasid adhered to the classification and terminology of Avicenna with no change [18. P. 66], as he studied Al-Hadd (definition) within two arts, the first of which is looking at the connotation of words than the meanings and the division of terms between them. The second part examines the relationship of

\footnotetext{
${ }^{1}$ This opinion is adopted by a group of researchers such as:

- De Boer T.J. Tarikh Al Falsafa Fi Al-'Islam (History of philosophy in Islam) [5. P. 200];

- Duhem Pierre. MasadirAlfalsafa Al-Arabiya, Tarjamato Abu Yaarub Al-Marzuqi [10. P. 136].
} 
meanings to one another, the division of assets into subjective and incidental, and a presentation of the definition of the boundary and the issues of errors in definitions [Ibid. P. 63].

Influenced by the statements of Avicenna, Hujjat al-Islam also confiscates another Sunni division, which is the division of expressions from the meanings [21. P. 92-93], where the Imam divided meanings into five categories, which are as follows: complicit, synonymous, divergent, familiar, and asserted [22. P. 18]. There is an unmistakable resemblance between the two men in their separation between the study of expressions and meanings on the one hand and the discussion of the limit and quotations on the other hand. It is worth mentioning that Avicenna talked about this part in his book Annajat (Deliverance), and Abu Hamid followed that in Al-Mi'yar (Science Standard) and Al-Mihaq (Touchstone of Consideration) [18. P. 68].

Al-Jabri considered Al-Mi'yar to be one of the most logical works of Al-Ghazali for two main reasons. First, the disclosure of the meanings of the idioms that philosophers colluded with, which he examined in Tahafut. Secondly, spreading an understanding of the ways of thinking and consideration and enlightening the measurement paths and lessons to enable the book to be a scale for consideration and research [23. P. 26-27]. Mi'yar al-'Ilm was Al-Ghazali's second logical work according to the date of its authorship, as it came after Maqasid and before Mihak al-Nadhar [18. P. 66]. Abu Hamid presented in Al-Mi'yar logical views mixed with a tendency to include some Islamic terms and examples, but the nature of the general book in terms of categories, chapters, and contents is merely a continuation of the process of presenting Aristotelian logic in its peripheral Islamic form, as was done by Avicenna [Ibid. P. 66].

The presence of Avicenna was noticeable in Al-Mi'yar of the Hujjat al-Islam. This presence is noticed firstly in the narrative of Al-Ghazali in regard to the study of limit. Secondly, when he spoke about Qiyas, which is a continuation of the spirit of Avicenna that appeared in the objectives by making the Qiyas in its simplest form a compound saying [Ibid. P. 141, 142]. The narratives of Abu Hamid regarding the study of the limit of the Mi'yar indicate that the explanations and divisions of Avicenna influenced him. As such, the spirit of the limit remains in this book as an extension of the matter in the objectives and a continuation of the Aristotelian trend despite some jurisprudential examples and linguistic expressions [Ibid. P. 83]. We caution that the study of the limit in the Mi'yar has been linked to the ten categories' engagement, where the author of this work mentions in the suffixes of the limit the categories of suffixes. The Masha'iyyah (Peripatetic) school considered the categories as metaphysical research, as the Masha'iyya of Islam (Islamic Peripatetic) did not single out detailed studies in their logical classifications but rather attached them. Therefore, we found that Avicenna had incorporated them into Al-isharat (Signals) within his logical proposition before Al-Ghazali appended them in the Mi'yar to study the limit, as aforementioned. Averroes, Being the exception, devoted a separate text to the Maqulat (categories), which is Talkhis Kitab al-Maqulat (Summarising a Book Categories) [Ibid. P. 82 -83]. 
Despite what has been presented, we notice that Abu Hamid's logic was distinguished from the logic of Masha'iyyat (Peripateticism) al-Farabi and Avicenna. These two comprehended Aristotelian logics and its Greek additions and were influenced and transmitted it. They, afterward, expressed it in the Arabic language, so their production acquired some of its features. Whereas Al-Ghazali was the only one representing the peripheral logic, harnessing it and normalizing it with Islamic meanings. Accordingly, Greek logic lost many meanings in its context and emerged in an Islamic form. Therefore, it is safe to state that Al-Ghazali's logical product was not an essentially conciliatory work. Instead, this latter produced a model for how logic is represented in the Islamic structure and how it normalizes its elements [Ibid. P. 10-11].

\section{Conclusion}

The reading of Muhammad Abed al-Jabri was and is still one of the wealthiest contemporary readings of our Arab and Islamic heritage, but this does not mean that it has put everything in its place. While we were preoccupied with Al-Ghazali's studies, we confiscated our scholar's opinion, the author of Naqd Al- 'aql Al- 'Arabī, according to whom Abu Hamid was and still is one of the most influential yet controversial figures in Arab-Islamic culture. He is an intellectual phenomenon challenging to classify in the context of what is circulating within our heritage space. In many cases, the Hujjat al-Islam works transmit to us the positions we know nothing about that may appear contradictory unless we have a law to which we refer, and this law, in our judgment, will only be a commitment to the chronology of the books. The arbitrary dealing with the corpus of Al-Ghazali can make the image uneven and sometimes even distorted, especially since this latter, as testified by himself in the Savoir, has gone through difficulties and experiences that fertilized his thought.

\section{References}

[1] Al-Jabri MA. Nahnu wa al-turāth [The Heritage and Us]. $6^{\text {th }}$ edition. Beirut: Centre for Arab Unity Studies; 1993. (In Arabic).

[2] Al-Jabri MA. Muqawinat fikr Al-Ghazali [Components of Al-Ghazali's thought]. In: Abu Hamid Al-Ghazali: Dirasat fi fikrihi wa asrihi wa ta'thirihi [The components of the thought of Al-Ghazali. In: Abu Hamid Al-Ghazali: Studies on his thought, his era, and its influence]. Arribat; 1988. (In Arabic).

[3] Al-Jabri MA. Al-Turath Wa-Al-Hadathah Dirasat - Wa-Munaqashat [Heritage and Modernity: Studies and Discussions]. Markzdirasat al-Wahda al-Arabiya. $1^{\text {st }}$ edition. Beyrouth; 1991. (In Arabic).

[4] Al-Jabri MA. Naqd Al-'aql Al-'Arabĩ: Taqwin al-'aql al-'Arabi [Critique of Arab Reason: The formation of the Arab mind]. $8^{\text {th }}$ edition. Dar Albaydae; 2000. (In Arabic).

[5] De Boer TJ. Tarikh Al Falsafa Fi Al-'Islam [History of philosophy in Islam]. $5^{\text {th }}$ edition. Beyrouth; Dar Annahda al'-Arabiyya; 1981. (In Arabic).

[6] Alami HA. Alfaylasuf Al'-Ghazali: Moraja'aton li al-mashhur [Philosopher Al-Ghazali review of the famous]. In: Hérminutica, éstética, théologia. 2007. (In Arabic). 
[7] Ibn Rushd Abu Al Walid. Fasl Al-Maqal fi ma Bayna Chari'atiwa Al-Hikmati min Itisal [The decisive speech Between the law and the wisdom of the connection]. $1^{\text {st }}$ edition. Beyrouth; 1997. (In Arabic).

[8] Jabre F. La notion de certitude selon Ghazali dans ses origines psychologiques et historiques. Paris: J. Vrin; 1958. (In French).

[9] Badawi Abd al-Rahman. Mu'allafat Al'-Ghazali [Writings of Al-Ghazali]. Al-quwayt; 1971. (In Arabic).

[10] Duhem P. Masadir al-Falsafah al-'Arabiyyah. $1^{\text {st }}$ edition. Dimashq; 2005. (In Arabic).

[11] Wensinck AJ. La pensée de Ghazzali. Paris; 1940. (In French).

[12] Badawi Abd al-Rahman. Al-Ghazali wa Masadiruhu Al-Yunaniya [Al-Ghazali and his Greek source]. In: Abu Hamid Al-Ghazali fi diqra Al-miawiya Attasia li miladihi. Mihrajan Al-Ghazali. Dimashq; 1961. (In Arabic).

[13] Al-Janabi M. Al-Ghazali. $1^{\text {st }}$ edition. Dimashq: Dar Al-mada; 1998. (In Arabic).

[14] Nakamura K. An Approach to Ghazalis Conversion. Orient. 1985;21:46 - 59.

[15] Ibnu Khaldun. Al-Moqaddimah [Introduction]. ${ }^{\text {rd }}$ edition. Beyrouth. (In Arabic).

[16] Al-Jabri MA. Binyat al-'aql al-'Arabi [The structure of the Arab mind]. Beyrouth; 1976. (In Arabic).

[17] Al-Alawi SB. Al-khitab Al-Ash'ari: Musahamatun fi Dirasati Al-Aql Al-Arabi Al-Islami [Ash'ari discourse]. Beyrouth: First edition; 1992. (In Arabic).

[18] Al-Ajam R. Al-Manteqinda Al-Ghazali fi Ab'adihi Al-Aristawiya wa khususiyatihi Al-Islamiya [Logic for Al-Ghazali in its Aristotelian dimensions and Islamic peculiarities]. $1^{\text {st }}$ edition. Beyrouth: Dar Al-Mashreq; 1989. (In Arabic).

[19] Al-Naqqari H. Al-Manhajiya Al-Usuliyawa Al-manteq Al-Yunani Min Khilali Abi Hamid Al-Ghazali wa Taqiy Addine Ibn Taymiyah [Fundamentalist methodology and Greek logic through Abu Hamid Al-Ghazali and Taqiyaddine Ibn Taymiyyah]. $1^{\text {st }}$ edition. Dar Walada;1991. (In Arabic).

[20] Bernand M. Al-Ghazali artisan de la fusion des systémes de pensée. Journal asiatique. 1990;LXX. (In Arabic).

[21] De Libéra A. La philosophie médiévale. 5éme edition. Paris: PUF; 2001. (In French).

[22] Al-Ghazali Abu Hamid. Maqasid Al-Falasifa [The purposes of the Philosophers]. Beyruth: Dar Al-Qutub Al-Ilmiya; 2003. (In Arabic).

[23] Al-Ghazali Abu Hamid. Mi'yar al-'Ilm fi Al-Manteq. $1^{\text {st }}$ edition. Beyruth: Dar Al-QuTub Al-Ilmiya; 1990. (In Arabic).

\title{
About the author:
}

Lachkar Mohammed - Professor of philosophy, Faculty of Arts and Humanities, Moulay Ismail University, Meknes, Morocco (e-mail: med_lachkar@yahoo.fr).

\section{Образ Аль-Газали в трудах Аль-Джабри}

\author{
М. Лачкар \\ Университет Мулая Исмаила, \\ Morocco, Meknes, BP:298, Marjane 2, Presidency, \\ med_lachkar@yahoo.fr
}

Аннотация. Мухаммад Абед Аль-Джабри (1935-2010) - известный философ и ученый, представитель современной арабской мысли. Он автор философии «арабского ума» и «критики арабского ума», пытавшийся разработать собственную теорию для 
изучения арабского наследия древности и современной арабской мысли. Аль-Джабри рассматривал их с критических позиций, методологические основы которых он заложил в своих основных философских трудах, в первую очередь, в трилогии «Критика арабского разума». Автор статьи анализирует и изучает различные аспекты аналитического и критического подхода Аль-Джабри к Аль-Газали и его теоретическим построениям. Помимо выявления особенностей собственной позиции на интеллектуальном пути Аль-Газали, основанной на изучении его книг, Аль-Джабри комплексно рассматривал личность Аль-Газали, которую трудно определить точно, целиком и полностью. Однако это не лишает его возможности описать критерии науки в целом и философии в частности. В статье отмечается, что позиция самого Аль-Джабри является в некотором смысле продолжением проблематики и сложности самого Аль-Газали. Аль-Джабри поднял больше вопросов, чем дал ответов, оставив и усилив противоречия. Исследование личности и творчества Аль-Газали, по-видимому, будет продолжаться еще долгое время по причине комплексности самого автора, а также разнообразия его интеллектуальных и творческих трудов, и сложного характера. Настоящая статья привносит свой вклад в этот дискурс.

Ключевые слова: Аль-Газали, Аль-Фараби, Аль-Джабри, ашаризм, арабский разум, критика арабского разума, Авиценна, эзотеризм, Ибн Рушд, исмаилизм, мутазилизм, суннизм, шиизм, Тахафут аль-Фаласифа

\section{История статьи:}

Статья поступила 05.08.2020

Статья принята к публикации 01.01.2021

Для цитирования: Lachkar M. Al-Ghazali's Image in Al-Jabri's works // Вестник Российского университета дружбы народов. Серия: Философия. 2021. Т. 25. № 2. С. 233-249. DOI: $10.22363 / 2313-2302-2021-25-2-233-249$

\section{Сведения об авторе:}

Лачкар Мохаммед - доктор философии, профессор, Университет Мулая Исмаила, Мекнес, Марокко (e-mail: med_lachkar@yahoo.fr). 